\title{
SOCIO-SPATIAL DIFFERENTIATION IN WARSAW: INERTIA OR METAMORPHOSIS OF THE CITY STRUCTURE?
}

\author{
MACIEJ SMĘTKOWSKI \\ Centre for European Regional and Local Studies (EUROREG), University of Warsaw \\ Krakowskie Przedmiescie 30, 00-927 Warsaw, Poland \\ E-mail: msmetkowski@uw.edu.pl
}

\begin{abstract}
The major dimensions to socio-spatial disparities in Warsaw are discussed, in relation to the pre-1989 situation, the study using data from 2002 National Census enumeration areas, for which PCA was carried out. The factors shaping the socio-spatial structure of Poland's capital are seen to have become similar to those observable in Western European cities, the key dimensions underpinning existing differences connecting with family or socio-economic status and social marginalisation. That said, spatial structures that evolved earlier are seen to have manifested marked inertia, not least with the classification of census areas pointing to similarities between individual units, not only as regards the prevalent character of buildings, but also where the time of construction is concerned. The inflow of new residents (including students) into Warsaw has represented a significant dimension to the differentiation, but has not generated any important changes in the capital's social space. In essence, the twin processes of transformation and metropolisation are found to have reinforced yet further disparities which had been discernible earlier, without any visible reshaping of their spatial distribution.
\end{abstract}

Key words: socio-spatial differentiation, principal component analysis, Warsaw, spatial structure.

\section{INTRODUCTION}

There can be no doubt that Europe's systemic transformation (in its initial period above all), was one of the crucial factors affecting cities continent-wide (Hall 1993). On the other hand, this period was also characterised by the lack of any data that would support syntheses or model summaries of the transformation processes, especially those highlighting their spatial aspects (Musil 1993). At the same time, quite paradoxically, it could be observed that the changes taking place in the urban areas of post-communist countries were akin to those observable in Western Europe (Nowosielska 2005). According to E. Nowosielska, these changes in- cluded: demographic processes (ageing and population decrease, though showing some variations depending on city size) and economic restructuring processes (associated with the collapse of some industrial plants and deindustrialisation), which in effect led to such phenomena as unemployment, the increasing dilapidation or even degradation of some of the old housing stock and the need for the revitalisation of former industrial areas (in many cases located in central city districts).

It should be noted that population decline has been primarily discernible in central city districts (e.g. in Ljubljana (Rebrenik 2005) or Prague (Sykora 1999), a process further 
strengthened by the most tangible functional changes. In parallel, and in broader spatial terms, suburbanisation processes (whereby the role of cities within their administrative boundaries was relatively reduced, and that of their suburban zones increased) became visible, while the regional hinterlands of the major cities were weakened even further, as a consequence of migratory outflows of young and well-educated individuals (cf. Smętkowski 2005).

Overall, the key effect of the transformation processes was the way in which quantitative urban growth, as expressed in terms of population increase, gave way to qualitative changes in economic, social and spatial urban structures (Parysek 2005).

There is no doubt that the above processes were to be observed in Warsaw also, though here there was an expectation that the Polish capital might stand out-in comparison with smaller cities thanks to progress with processes of metropolisation, but also as a reflection of the enormity of the devastation the city suffered during World War II, and consequently of the enormous scale on which post-War reconstruction took place.

Warsaw was unquestionably the Polish city to develop most dynamically in the course of the economic transition. The capital was soon dubbed the leader of the transformation (including in regard to privatisation processes), and became the urban centre capable of attracting most inward FDI. This was manifested, not only in the growing number of transnational corporations that chose Warsaw as the seat of their Polish subsidiaries, but also in a rapid development of advanced producer services (including finance and ICT) cápable of catering to the needs of the companies in question (cf. eg. Kukliński 2004). All of this reflected a range of factors which went beyond capital city status to include relatively good accessibility (at least in comparison with other Polish cities) owing to the presence of an international airport; high-quality human resources; a well-developed tertiary education sector and existing R\&D potential. Fur- thermore, Warsaw saw a rapid development of micro-enterprises, that attested to its residents' capacity to seize opportunities the market economy had opened up. The success of the transformation was also backed up by the keen interest both domestic and foreign developers showed in such extensive development projects as those involving office buildings, shopping malls and housing estates (cf. e.g. Jatowiecki 2000). In addition, Warsaw proved to be a venue for rapid deindustrialisation, as manifested in the liquidation of existing production assets and a gradual development of post-industrial areas that acquired new functions, especially in relation to higher-order services.

It should be noted that these changes arose, not only out of the transition from a centrally-planned socialist economy to a free-market capitalist one, but also through a transition from an industrial (Fordist) to an information (post-Fordist) economy, a process not immediately tangible during the initial phase of the transformation (cf. Gorzelak 1995). Currently, it is metropolisation processes occurring at different spatial levels that are the main factors shaping the space in the large cities, in the developed countries in particular (Castells 1989). In the social dimension, these are predominantly manifested in growing polarisation within cities or metropolitan areas. At the one extreme, there is the cosmopolitan metropolitan class, at the other local lower social classes or groupings formed by emigrants from countries at a lower level of development. Representatives of the former class typically work in the sector of modern services associated with management or control functions, or in sectors of the knowledgebased economy, whereas those from the latter provide simple services such as cleaning, security, municipal services, transport or retail trade. These groups differ markedly in terms of place of residence, the former frequently occupying high-end apartments or suburban residences, while the latter reside most often in run-down districts both in the city centre and on the peripheries (cf. Jałowiecki 2000). The processes referred to 
are also to be observed in the Polish capital, albeit to varying degrees.

The major morphological and functional changes that have characterised Warsaw in recent times have been outlined in many papers and studies that have summarised the development and location of state of-the-art office buildings, huge shopping malls and new residential estates (e.g. Węclawowicz 2002; Śleszyński 2004, 2006; Smętkowski 2009a, Wilk 2001, 2005). Social changes in the city were likewise discussed in the publication edited by Grzelak and Zarzycki (2004). However, the latter work did not take the spatial dimension to changes into account, save where it alluded to maps offering evaluation of urban space (Lewicka 2004), as well as case studies performed for selected residential estates (Jałowiecki et al. 2004).

In spatial terms, ongoing changes are manifested in different forms of gentrification of central districts (cf. e.g. Lisowski 1999), coupled with a simultaneous outflow of population to suburban areas-i.e. suburbanisation. Recently, there has been a visible intensification of both processes on account of their having been reinforced by the inflow of emigrants from the region surrounding the city and from other parts of Poland (Gorzelak and Smętkowski 2005), as well as-more and more frequently now-from abroad (Grzymala-Kazlawska and Piekut 2007). At the same time, growing disparities in levels of wealth are evidenced by the increasing popularity of gated communities (Gąsior-Niemiec et al. 2007) and the evolution of elite spaces (Węclawowicz 2008), at the same time as petrification of traditional pockets of poverty is ongoing (Węcławowicz 2001).

All of the above serves to beg a question as to whether the processes referred to are transforming the socio-spatial structure of Warsaw significantly. Unfortunately, in the circumstances of a lack of valid data at a level of aggregation lower than the individual district, no satisfactory answer can be provided. However, a more detailed picture can be obtained on the basis of data contained in the 2002 National Census, an analysis of which is able to offer a starting point from which to consider further the social dimension to the metropolitan processes taking place in Warsaw.

Factor ecology is a method that has proved quite useful in portraying socio-spatial disparities in cities. It dates back to the 1960 s, at which time it gained considerable currency, in the United States especially. Factor ecology distinguishes three key dimensions to disparities in urban space, i.e. family status adopting a concentric form; economic status in sectoral form and ethnic status of a patchy nature (e.g. as in Pacione, 2001, pp. 351-352). Such studies were also conducted in pre-1989 Poland, and their findings can therefore serve as a frame of reference for a factor analysis employing data from the 2002 National Census of Population and Dwellings (NSLiM).

\section{THE STRUCTURE TO SOCIAL SPACE IN PRE-1989 WARSAW}

At the outset, it needs to be recalled that the transformation process already referred to occurred in the conditions specific to cities in post-communist countries. Nevertheless, it was in the cities of Poland perhaps most of all that the post-War reconstruction effort needed to be so vast and all-embracing, with $85 \%$ of buildings in Warsaw having been destroyed, for example. This gave particular weight to a shaping of post-War sociospatial structures that was subordinated to the requirements of a new political regime in the process of being installed, hence the particular value of Poland's capital in exemplifying a more universal phenomenon. The major characteristics of cities in the old Eastern Bloc exerting a strong influence on their space include (cf. Węclawowicz 2007, pp. 141-142): a prevalence of employment in industry, as associated with the leading role in the system that the working class was supposed to play; extensive development in urban space caused by complete disregard for the phenomenon of land rent; and 
a relatively high degree of social homogeneity in terms of class and economic status.

The socio-spatial disparities existing in Warsaw prior to the economic transformation have been well-publicised in the works of G. Węclawowicz, who in 1975 compared these structures with the pre-War situation, and in 1985 sought to set the situation in Warsaw against that in other Polish cities. A further boon was the publication of the "Atlas of Warsaw" (Atlas Warszawy) (Węclawowicz and Księzak 1993, 1994), which portrayed selected aspects of the pretransformation disparities present in urban space (including as regards demographics, education and professional status).

According to Węclawowicz (1975), the major dimensions to the socio-spatial disparities in communist-era Warsaw concerned:

(a) social and career status, as manifested in level of educational attainment and membership of artistic and intellectual elites or the civil service, this being associated indirectly with a high share of state-owned apartments;

(b) housing and social status, in relation to a large percentage of the apartments built before World War II or directly thereafter, coupled with an egalitarian mixing of various vocational groups, e.g. blue- and white-collar workers;

(c) economic status, revealed in a wealthiest group in the population at that time comprising managers and the self-employed, who enjoyed relatively the most freedom in choosing place of residence;

(d) family status, as associated with extended families including both members of pensionable age and children.

With such diverse dimensions in plàce simultaneously, the structure to Warsaw's social space was rather patchy (Węclawowicz 1975), and included elements typical for the sectoral wedge-shaped pattern described by H. Hoyt (1939), the concentric model proposed by E.E. Burgess (1925), and polycentric development, compliant with the concept devised by C.D. Harris and E.L. U1lman (1945). This system was much affected by the destruction wrought by the Second World War, and by the pattern of post-War reconstruction that was adopted.

It should also be noted that Warsaw's socio-spatial structures developed under conditions of rather strict control over resident registers, and a policy entailing the domination of state- or cooperative-owned apartments, which inevitably meant little leeway for city residents in this respect, and resulted in an egalitarian mixing of different social groups and relative homogeneity of the social milieu. This meant in turn that ecological concepts could not be generalised to explain the social and spatial structure of Warsaw (Węclawowicz 1975, p. 106).

Due to the low quality and poor availability of the data compiled in the 1988 census, it did not prove possible to perform an exercise of the above kind for that period. Some information from that source was nevertheless used in the aforementioned Atlas Warszawy (Węclawowicz and Księzak 1993, 1994). From that, it is to be concluded that the family situation and associated distribution of people of different ages across the city space was concentric in character, with a prevalence of elderly people, one-person and two-person households in the central districts, and of younger people as well as three or four-person households in the new estates being developed at some distance from the city centre. Households composed of five of more persons were mostly a phenomenon characteristic of peripheral districts.

On the other hand, an analysis of the social and career status associated with the level of education and the nature of work performed pointed to a sectoral distribution of disparities, with a clearly-delimited belt intersecting the city centre in the northsouth direction. This area was largely inhabited by residents with tertiary education, whereas eastern parts of the city as well as its western peripheries (with the exception of the predominantly-military district of Bemowo) were for the most part inhabited by people with more limited educational attainments. According to Węclawowicz 
and Księżak (1993), from as early as in the 1970 s, processes of competition and segregation of the population were accompanying new housing development, with people of higher social status settling in 'superior' estates, while those of lower status fetched up in 'inferior' districts. In effect, as is pointed out by some authors (Dangschaut and Blasius 1987, after: Węclawowicz and Księzak 1993), the 1980s brought a widening of socio-spatial disparities, up to a level comparable with those in Western European countries.

\section{CONTEMPORARY DIMENSIONS TO WARSAW'S SOCIO-SPATIAL DISPARITIES}

There was a reasonable expectation that nearly two decades of the operation of market mechanisms would have led to visible changes in the social space of Warsaw, most especially in circumstances of a lack of more servere administrative restrictions.

To check on this, data from the 2002 National Census were used in an analysis of the contemporary socio-spatial structure of Poland's capital that could be carried out at a low level of aggregation, i.e. for the statistical areas made use of in the Census. If the municipality of Wesola is added in, Warsaw is seen to consist of no fewer than 1442 such areas, with the bonus of relative similarity in population terms, an average population size of 1170 being associated with an extreme range from as few as 10 (with 11 areas supporting less than 300 people) to as many as 3373 (with 7 areas having populations over 2500 ). Unsurprisingly, such relative homogeneity of population size in the great majority of statistical areas was achieved through marked differences in area size: 35 ha on average, but extending across a range between 0.4 ha and more than $21 \mathrm{~km}^{2}$. To a considerable degree such size differences were also associated with components of technical infrastructure such as airports or railway lines, or else components of the natural environment such as forests, watercourses, etc.
It was possible to analyse socio-economic structure on the basis of intentionally selected indicators or else in an exploratory manner, using the broadest possible set of variables. The work described here based itself on the latter method, with principal components analysis therefore being employed to reduce the number of indicators investigated, this in turn allowing major dimensions to existing differences to be identified (cf. Chojnicki et al. 1978). In selecting characteristics for analysis, account was taken of various aspects related to features of population and the housing stock, and most especially ${ }^{1}$ :

- demographic features (gender, age, marital status);

- socio-economic features (education, occupational activity, source of income);

- characteristics of households (household composition, family profiles);

- the condition and quality of housing stock (ownership profiles and functions of dwellings, housing conditions);

- migration processes (inflow population, settledness, foreign emigrants).

Subsequently, the number of variables was reduced using the correlation-factor method proposed by Gorzelak (1979), which eliminates "irrelevant" variables on the basis of their being characterised by low variation coefficients (an adopted value of 0.1 in our case) and a high correlation ( 0.9 in our case), or else being weakly correlated with the selected factors before the rotation (we adopted the value of 0.4 ).

As a result, out of a set of 75 variables selected tentatively at the outset, 63 were ultimately used in the factor analysis. However, by using the 'scree' test (cf. Cattell 1966), we were able to identify five principal components showing the differences between Warsaw's statistical areas and accounting for $62.1 \%$ of total variance (see Annex 1). Among the five were the three basic bi-polar components expounded on below,

${ }^{1}$ The distribution of some of these indicators across the city space is shown in Atlas Warszawy 11 (Stępniaket al., 2009). 
1) Family status (19.1\% of total variation), which clearly distinguished statistical areas lying at either extreme, viz.:

- areas with a high share of three- and four-person households composed of working parents (as a rule are in paid employment and quite frequently working in managerial positions), who support children aged under 24 and have a relatively good housing situation (with apartments or houses of floor area between 50 and $100 \mathrm{~m}^{2}$ often built in the 1970s and 1980s);

- areas with a high share of older persons living on their own (widows/widowers or divorced), with small flats (frequently municipally-owned) in many cases built in the post-War period (1945-1970).

2) Social and economic status $(14.3 \%$ of total variation) - a component differentiating statistical areas in terms of the education and career status of residents and bringing into sharp relief two most-typical situations involving:

- areas with a large share of people with tertiary education, usually professionals, whose housing situation was very good (a large $\left(100 \mathrm{~m}^{2}\right.$ or more) floor area per person in apartments or houses), with a relatively high proportion of people born outside Poland-including immigrants from highlydeveloped countries (and, to a lesser extent also Vietnam); in many cases this meant that apartments and houses were also seats for business activity;

- areas with a large share of people with vocational education (and, to a lesser extent, primary or secondary education), usually workers, craftsmen or personnel employed in the service sector (less frequently office personnel and employees in elementary occupations), which implied more labbour mârket problems (a relatively high unemployment rate); these would occupy small flats of floor areas up to $50 \mathrm{~m}^{2}$, frequently owned by housing cooperatives.

3) Social marginalisation $(12.8 \%$ of total variation)-a component pointing indirectly to the poor material situation of some residents in a given statistical area, as associated with a relatively large share of people with elementary education who would as a rule hold lowly paid jobs not requiring any special qualifications (including agriculture), and a bad housing situation manifested by a large share of substandard flats in rundown buildings built before World War II (owned by the municipality or in private hands), but in many cases inhabited by families with many children. On the other hand, this meta-feature brought to light those social groups not succumbing to marginalisation, i.e. the lower middle class in industrial society, mostly technicians and professionals, who reside in cooperativeowned housing stock built in the 1970s and 1980s.

The above three components were supplemented by two more dimensions to differences in which the spatial system was of a mosaic nature, and the statistical distribution visibly differed from the typical one (with high skewness and kurtosis values):

4) The post-1988 inflow population (5.7: $9.1 \%$ of total variation) - this component highlighted areas largely inhabited by an inflow population (coming mostly from regional capitals) aged $25-40$, as a rule living in newly-built apartment buildings, or else a long-settled population as a rule either born in Warsaw or coming here prior to 1988, in the 40-65 age group.

5 ) Young people and students (6.8\% of total variation) - this component attained high values in areas inhabited by a population aged $15-24$, mostly people coming into Warsaw from rural areas and typically possessing secondary education and sharing flats with a number of other tenants.

The evaluation of the diagnostic values of the above components is enhanced through an nălysisis of their spantiāl diștribution (Fig. 1) as set against Warsaw's current division into residential districts (Fig.2)

The first demographic factor pointed to a concentric distribution of spatial disparities. The city's central districts are inhabited by older people (frequently old age pensioners), living alone. On the other hand, families with children as a rule live in newer residential estates (built in the 1970s and 1980s), 


\begin{tabular}{|c|c|c|}
\hline $\begin{array}{c}\text { Component (1) } \\
\text { 'Family status' }\end{array}$ & $\begin{array}{c}\text { Component (2) } \\
\text { 'Socio-economic status' }\end{array}$ & $\begin{array}{c}\text { Component (3) } \\
\text { 'Social marginalisation' }\end{array}$ \\
\hline & & \\
\hline
\end{tabular}

Figure 1. Spatial distribution of principal components scores for socio-spatial differentiation

Source: author's own elaboration.

situated $5-10 \mathrm{~km}$ from the city centre, as well as in newly-built residential estates in the southern and northern parts of the city. This component also produced high values in rural areas undergoing urbanisation, situated in peripheral city districts.

The spatial distribution of the socioeconomic component was largely sectoral; it identified districts inhabited by groups of varied social and career status. The northsouth axis running across the city centre along the escarpment on the left bank of the Vistula River was particularly visible. Certain enclaves could also be observed clearly, fơr instance the districtss of Sāská Kępá (on the right bank of the river) and Szczessliwice (south-western area). On the other hand, low values were observable along the east-west axis (which to some extent corresponds with the main railway routes and the adjoining industrial areas). In the west, this includes the former workers' district of Wola, and in the east-Praga, the district with the worst reputation. The other dimension to differences in this component involved a north-south pattern. In this regard, lower values were recorded in the northern peripheral districts of the city (the vicinity of the Warsaw Steel Plant and the peripheral right-bank district of Białolecka), and in the south only in the industrial part of Służewiec and the central part of the city's largest residential districtUrsynów. At the same time, high scores for the factor were commonly associated with the remaining peripheral districts in the south and south-east, which could be seen as proof of internal suburbanisation processes within the city.

The third factor, relating to social marginalisation, was partly concentric and partly sectoral in shape. On the one hand, high values could be observed in the peripheral 


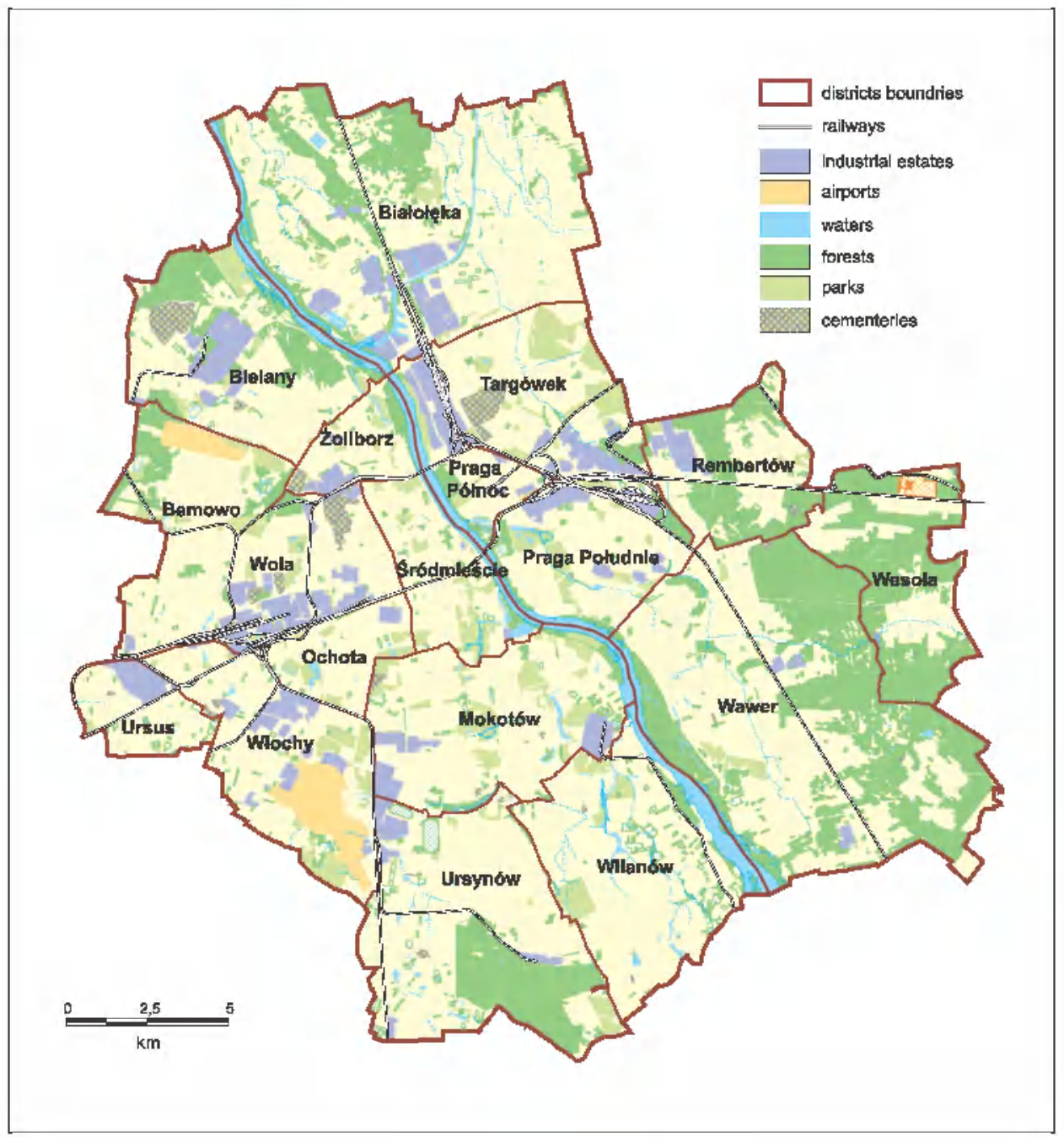

Figure 2. Districts of Warsaw

Source: author's own elaboration.

boundary areas which were earlier predominantly agricultural, and on the other certain elements of a sectoral system were observable, in the form of downtown poverty, in the districts of Wola, Sródmieście (southern part) and Praga. This particular component manifested considerable heterogeneity from one urban block to another.

The fourth component was associated with the inflow of population from outside Warsaw after 1988; it mainly delineated key areas of housing activity, usually situated in the vicinity of housing estates built in the 1980 s, as ownership issues connected with land have been fully resolved and these areass have a well-developed technical infràstructure.

The fifth component relating to students showed some correlation with the location of higher education institutions (the University of Warsaw, Military University of Technology, Cardinal Stefan Wyszyński University, 
Warsaw School of Economics), and some lower-end housing estates.

It is worth re-emphasising that the variables differentiated above can only account for some of the socio-economic differences observable in Warsaw (62.1\% of overall variation in fact). In addition, certain statistical areas and urban blocks are seen to display considerable internal disparities, a fact that is seen to attest to marked social contrasts, as manifested for example by neighbourhoods in which detached houses stand alongside municipal tenement houses, or new singlefamily housing developments adjoin farms or smallholdings in semi-rural areas.

The adopted factor analysis of differences in the socio-economic space of Warsaw was used in classifying Warsaw's statistical areas. To date, such a method has rarely been applied in the Polish literature on the subject and, as a rule, only in relation to two or three principal components (e.g. Węclawowicz 1975; Jaroszewska-Brudnicka 2004). However, all the principal components were used in classifying the provinces (voivodships) existing at the time, and variables showing the age structure were used by J. J. Parysek (1989), who also pointed to difficulties with interpreting the results obtained.

A classification of the statistical areas was developed using the hierarchical cluster analysis, drawing on Ward's method to optimise the results (cf. e.g. Mlodak 2006). The outcome was the classification diagram reproduced below (Fig. 3), showing several clusters of elements with similar structure where the analysed measures (components) are concerned. In this case, the distinguished classes were not formalised, and the analysis of the dendrite structure as compared with the spatial distribution of the identified types played a crucial role in identification and nomenclature. As a result, the individual typological classes (based on their spatial distribution) (Fig. 4) and analyses of the average scores (Table 1) were named accordingly (although quite arbitrary in some cases), also using background

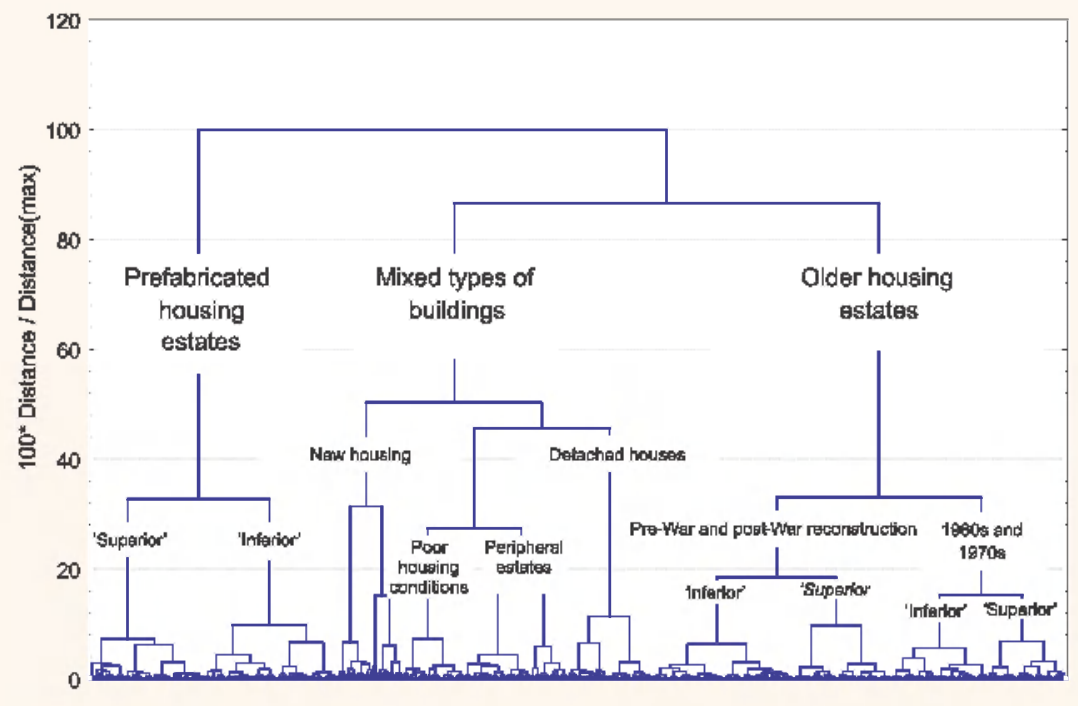

Figure 3. Classification of Warsaw's statistical areas

Source: author's own elaboration. 
information on the nature of the given area's development (Smętkowski 2009a, pp. 73-79; Studium uwarunkowań ..., 2006).

On this basis, three basic typological classes of regions were distinguished, and within these classes a number of significant sub-classes. The identified basic types were associated with the character of housing: 1) Prefabricated housing estates (mostly those which originated post 1975); 2) Mixed types of buildings (entailing considerable social disparities); and 3) Old housing estates (mostly those built before 1975). Housing features also governed the division into subtypes in Classes 2 and 3. While the former was strongly diversified internally, and its subtypes were associated with age, location and quality of housing, in the latter class the subtypes clearly pointed to the age of the housing. Moreover, as part of Type 1 and subtypes of Class 3, further subtypes were distinguished, which were arbitrarily termed 'superior' or 'inferior', depending on their social profiles. In a nutshell, the 'superior' housing estates showed higher values for indicators related to social and career status of the population and the share of the population accounted for by young people and students. Nonetheless, the 'inferior' estates produced only slightly higher values for the indicators showing the influx of new residents; this, however, could have reflected other factors such as lower housing prices. At the same time, however, the two subtypes did not differ more markedly in terms of values for social exclusion-related indicators, as in both subtypes no such phenomena could be observed on a large scale.

Table 1. Mean values for factor scores in the identified types of statistical area

\begin{tabular}{|c|c|c|c|c|c|}
\hline Type & $\begin{array}{l}\text { Family } \\
\text { status }\end{array}$ & $\begin{array}{l}\text { Socio- } \\
\text { economic } \\
\text { status }\end{array}$ & $\begin{array}{l}\text { Social } \\
\text { marginali- } \\
\text { sation }\end{array}$ & $\begin{array}{l}\text { Population } \\
\text { inflow } \\
\text { after } 1988\end{array}$ & $\begin{array}{l}\text { Youth and } \\
\text { students }\end{array}$ \\
\hline Type 1: Prefabricated housing estates & 0.78 & -0.53 & -0.83 & -0.57 & 0.15 \\
\hline a) 'superior'-multi-person households & 1.27 & -0.12 & -0.85 & -0.78 & 0.75 \\
\hline b) 'inferior'-low socio-economic status & 0.38 & -0.87 & -0.83 & -0.41 & -0.35 \\
\hline Type 2: Mixed types of buildings & 0.49 & 0.36 & 0.78 & 0.45 & -0.02 \\
\hline a) New housing - population inflow & 0.55 & 0.34 & -0.17 & 2.57 & 0.88 \\
\hline $\begin{array}{l}\text { b) Poor housing conditions-social } \\
\text { marginalisation }\end{array}$ & -0.09 & -1.29 & 1.71 & 0.17 & 0.08 \\
\hline $\begin{array}{l}\text { c) Peripheral estates-multi-person } \\
\text { households }\end{array}$ & 1.14 & 0.19 & 0.93 & 0.17 & -0.53 \\
\hline $\begin{array}{l}\text { d) Detached houses-s-high socio-économic } \\
\text { status }\end{array}$ & 0.10 & 1.78 & 0.66 & -0.66 & -0.19 \\
\hline Type 3: Older housing estates & -0.84 & 0.04 & -0.10 & -0.01 & -0.08 \\
\hline $\begin{array}{l}\text { a) Pre-War and post-War reconstruction- } \\
\text { 'superior': higher socio-economic stâtus }\end{array}$ & -0.90 & 0.54 & 0.39 & -0.12 & 0.20 \\
\hline $\begin{array}{l}\text { b) Pre-War and post-War reconstruction- } \\
\text { 'inferior': lower socio-economic status }\end{array}$ & -0.83 & -0.46 & 0.40 & -0.03 & -0.16 \\
\hline $\begin{array}{l}\text { c) } 1960 \text { s and } 1970 \text { s estates.-_superior': } \\
\text { higher socio-economic status: lack of } \\
\text { social marginalisation }\end{array}$ & -0.53 & 0.73 & -0.97 & -0.08 & -0.09 \\
\hline $\begin{array}{l}\text { d) } 1960 \text { s and } 1970 \text { s estates-'inferior'- } \\
\text { lower socio-economic status: population } \\
\text { in older age groups }\end{array}$ & -1.03 & -0.32 & -0.63 & 0.20 & -0.27 \\
\hline
\end{tabular}

Source: author's own elaboration. 
Overall, the classification generated, complex and somewhat arbitrary in nature as it may be, can tentatively be regarded as offering a quite accurate description of the characteristics of individual areas, as is evidenced indirectly by the occurrence of readily-identifiable spatial clusters for the categories distinguished.

The first distinct type includes housing estates built from prefabricated concrete, mostly developed after 1975 and situated 5 to $10 \mathrm{~km}$ from the city centre. In those types, two subtypes can be distinguished, which can be described preliminarily as 'superior' and 'inferior' in relative terms. In the former, three- and four-person households prevail, including those comprising people aged $15-24$, and with a high degree of long-term settlement. The latter subtype is associated with a lower social and career status and

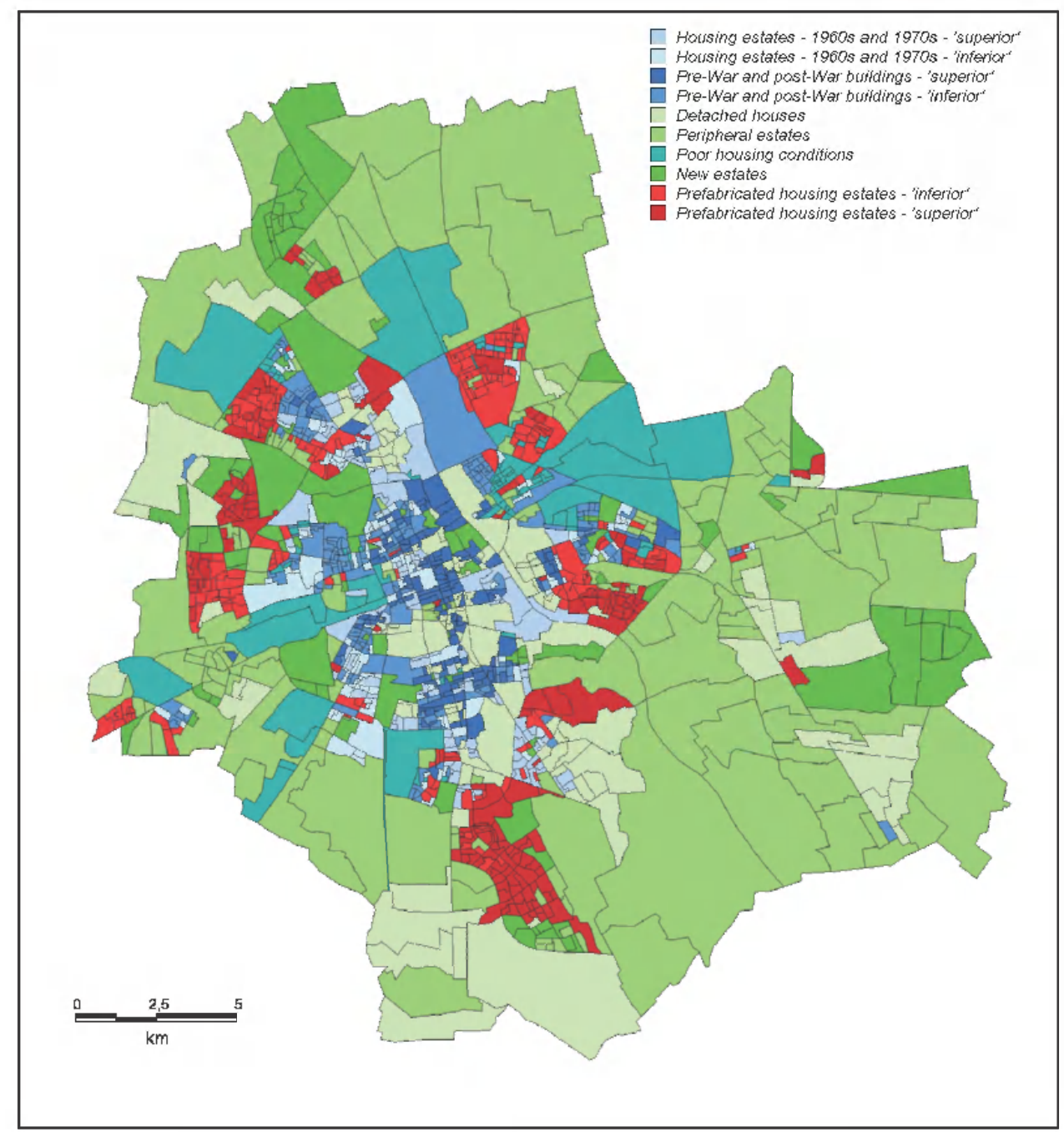

Figure 4. Typological classes of statistical areas in Warsaw 
lower-level occupational activity on the part of residents.

The second type of area was characterised by marked internal social disparities, with the concurrence of different types of building as a common denominator, usually in areas with a lower population density (larger statistical areas) or inhabited by people of varied social and career status. As a rule, these were areas of new developments in both single and multi-family housing, as was manifested in large inflow populations, as well as high values for the indicator relating to young people and students. The second subtype was associated with poor living conditions and a low social and career status of inhabitants-manifested in a low level of education and elementary occupations (mainly in the districts of Praga Polnoc and Wola). The third subtype could be described as comprising areas of morphological and functional transformation, mainly involving suburban rural areas undergoing urbanisation. The last subtype above all involved areas with single-family detached buildings, as a rule inhabited by people with a high social and career status, but (owing to the presence of (frequently) substandard municipal housing) also in many cases characterised by a relatively high percentage of people with poorer education and a lower social and career status.

The third type was mainly related to family situation and occupational activity and was represented by areas of contiguous residential housing developed before 1975 . It consisted of four subtypes represented by two similar pairs. The first pair comprised areas with a prevalence of pre-War buildings and buildings erected in the first phase of post-War reconstruction; it included neighbourhoods inhabited by people with a high social and career status (central parts of the city) and those with a low status (external peripheries of the city centre: districts of Wola, Praga and Bielany). A similar situation could be observed in the second pair which incorporated housing estates built in the 1960 s and 1970 s. This group, however, was characterised by a considerable intermingling of different subtypes.
To sum up, the proposed classification showed a correlation between the time at which individual housing estates were built and the social profiles of residents that is not perceptible at the level of particular components. This is mainly true for features related to age, i.e. family status and occupational activity, or education, i.e. career status and type of occupation. As a result, it was possible to distinguish the major types of area which in many cases formed spatially compact groups corresponding with individual housing estates. Also visible quite distinctly was the mosaic distribution of factors affecting changes in the spatial structure of the city, as associated with new areas of residential development, and with peripheral areas undergoing morphological and functional change.

The relative stability of socio-spatial disparities in Warsaw, which could be observed on the basis of a qualitative comparison of the situations in 1988 and 2002, is reflected in the analysis of segregation indices for five age groups and four groups of educational attainment in the years in question (Table 2). The analysis shows a slight reduction in the values for segregation indices for the youngest age groups and groups aged 40-64, and for the population with vocational or higher education. The latter results (other than the differences associated with the different number and changes in the statistical areas during the analysed period) were certainly affected by changes for the better in the educational structure of Warsaw's residents, as manifested in a substantial increase in the percentage of the population predominantly with tertiary, and less so with secondary education, and a considerable fall in the number of people with vocational education. While in the former situation this can be explained by the growing egalitarisation of the society in terms of education, a process which was also visible spatially, the latter phenomenon may suggest that the clusters of the population with vocational education in the housing estates formerly linked to industrial plants have gradually been becoming smaller. 
Table 2. Indices of dissimilarity (segregation) and their changes in the years 1998-2002

\begin{tabular}{lccccc}
\hline Age groups & \multicolumn{7}{l}{} \\
\hline & $0-14$ & $15-24$ & $25-39$ & $40-64$ & $65+$ \\
\hline $1998(\mathrm{~N}=1316)$ & 0.17 & 0.19 & 0.11 & 0.14 & 0.29 \\
$2002(\mathrm{~N}=1442)$ & 0.13 & 0.15 & 0.10 & 0.10 & 0.28 \\
Change & -0.04 & -0.04 & -0.01 & -0.04 & -0.01 \\
\hline \multicolumn{2}{l}{ Educational attainment } & & & & \\
\hline \multicolumn{7}{l}{} & Tertiary & Secondary & Vocational & Primary & \\
\hline $1998(\mathrm{~N}=1316)$ & 0.27 & 0.10 & 0.20 & 0.18 & \\
$2002(\mathrm{~N}=1442)$ & 0.21 & 0.06 & 0.10 & 0.17 & \\
Change & -0.06 & -0.04 & -0.10 & -0.01 & \\
\hline
\end{tabular}

Source: author's own elaboration.

\section{CONCLUSIONS}

The analyses conducted invite the conclusion that the existing system of socio-spatial disparities in Warsaw was driven predominantly by the boost in the city's population in the post-War period and the successive populating of new housing estates by social groups that were relatively homogeneous in terms of age and social status. Ageing processes led to the development of a concentric distribution of people in different age groups, which was manifested in their family status and household size. The poorly developed real-estate market and severe shortage of dwellings were factors contributing to the emergence of a model in which spatial mobility was constrained and any propensity for migration stifled. Nevertheless, the low quality of housing stock encouraged some people to leave their place of residence, a move which resulted in the development of the city's peripheral areas (including those which in many cases bordered with former housing estates), and in the suburbanisation of the outskirts.

On the other hand, the spatial distribution of the meta-feature indicative of social status that is manifested in educational attainment and the nature of work performed pointed to a significant permanence where the wedge-shaped pattern in the central parts of the city is concerned. This tradition- al pattern ran from the north southwards (higher socio-economic status) and from the east westwards (lower socio-economic status), something that can be seen to attest to the durable attractiveness of the housing estates located along the Vistula escarpment on the one hand, and on the other to a negative assessment of the close proximity of industrial areas located along railway lines. Although these also include some industrial estates (mostly in Wola district), the morphological and functional changes that have taken place so far have not as yet resulted in any marked change of this dimension to socio-spatial disparities. In contrast, a different pattern for disparities has become visible in recent decades, in association with a greater attractiveness of housing in the peripheral districts situated south of the city as compared with those located in the north.

The portrayal of social and economic disparities would not be complete without a third dimension associated with neglected older housing stock situated in the city centre (poor residents) and on the outskirts (farmer families with many children). As a rule, these dwellings are inhabited by marginalised social groups whose residents usually have primary education only and perform unskilled jobs.

The co-occurrence of the above dimensions to disparities in various forms has resulted in a considerable heterogeneity of 
many statistical districts, this being a characteristic feature of Warsaw that points to the minor role played by land rent during the city's development in the communist era. The current inertia in this regard results inter alia from unresolved ownership rights and the egalitarian policies of the city authorities regarding rent paid for social buildings.

These major dimensions to social and economic disparities are compounded by new processes related to the inflow of university students and new residents who mainly take up employment in the rapidly developing sector of higher-order services (cf. Gorzelak and Smętkowski 2005). In the former case, this implies a number of changes in the social structure in the vicinity of higher education institutions, and in the latter case it is manifested in the emergence of new housing estates. Nevertheless, in the period under analysis (2002), these processes took an irregular course and did not have any substantial bearing on change in the social or spatial structure of the city. Their key manifestation was the emergence of two new housing estates: Kabaty in the district of Ursynow and Nowodwory in the district of Bialolęka.

In conclusion, the patchy structure of the social space of Warsaw which characterised the 1970 s is seen to have given way to a more distinctive pattern of socio-spatial disparities, containing both concentric and wedgeshaped elements. However, it is clear that this pattern began to evolve before the onset of the transformation processes. Equally, the contemporary dimensions to the sociospatial disparities present in Warsaw are not seen to differ more markedly from those observable in other European cities (e.g. Bilbao, Lisbon, Rotterdam and Vienna (The GEITONIES Project Report, 2008), which are first and foremost associated with the family situation and the socio-economic status of the population. The main difference between them is that-so far-immigrants from developing countries have had little if any influence on the changes in the structure of Warsaw's social space. This is above all due to the relatively limited appeal of Poland as a target country for immigrants. Beyond that, it is also true that immigrants will often choose municipalities situated near Warsaw for their places of residence (vide some Vietnamese working in the trade centre located at Wolka Kosowska-some $22 \mathrm{~km}$ far from the city center). Thirdly, the relatively low level of social integration and distrust on the part of immigrants makes it difficult if not impossible to portray this phenomenon as part of the census taken.

The overall conclusion of the work done would therefore be that, notwithstanding distinct morphological and functional changes ongoing in Warsaw space, recent socio-spatial disparities have been marked by considerable inertia. Similarly, no significant metamorphoses of the city's social space should be anticipated in the near future, even though social disparities will certainly widen. At the same time, the processes shaping the structure of the social space in Warsaw should be considered to resemble in many respects those taking place in many cities of Western Europe.

\section{ACKNOWLEDGEMENTS}

This paper originated as part of the project entitled: Generating Interethnic Tolerance and Neighbourhood Integration in European Urban Spaces (7th Framework Programme of the European Union, Grant No. 216 184), which was implemented with the participation of the Centre for Migration Research at the University of Warsaw.

\section{REFERENCES}

Burgess, E.W. (1925), The growth of the city: An introduction to a research project, in Park, R.E., Burgess, E.W., McKenzie, R.D (eds.), The City, University of Chicago Press, pp. 47-62.

Castells, M. (1989), The Informational City, Blackwell Publishers, Oxford.

Cattell, R.B. (1966), The Scree Test for the Number of Factors, Multivariate Behavioral Research, 1(2): 245-276. 
Chojnicki, Z., Czyż, T., Parysek, J.J., Ratajczak, W. (1978), Badania przestrzennej struktury spoleczno-ekonomicznej Polski metodami czynnikowymi [Research on the socio-economic structure of Poland based on factor analysis]. Wydwnictwo Naukowe PWN, Warsaw-Poznań.

Dangschat, J., Blasius, J. (1987), Social and spatial disparities in Warsaw in 1978: An application of correspondence analysis to a 'socialist' city, Urban Studies 24: 173-191.

Gąsior-Niemiec, A., Glasze, G., Lippok, D., Pütz, R. (2007), Grodzenie miasta: casus Warszawy [Fencing of the city-the case of Warsaw], Kwartalnik Studia Regionalne i Lokalne, 4 (30), Wydawnictwo Naukowe Scholar, Warsaw, pp. 5-30.

Gorzelak, G. (1979), Dobór zmiennych w statystycznej analizie porównawczej, Część 1 [Selection of variables in statistical comparative analysis, Part One], Wiadomości statystyczne 3, 1979; Część 2 [Part Two], Wiadomości statystyczne 4, 1979.

Gorzelak, G. (1995), Transformacja systemowa a restrukturyzacja regionalna [The systemic transformation and regional restructuring], UNESCO Chair in Sustainable Development, University of Warsaw, Warsaw.

Gorzelak, G., Smętkowski, M. (2005), Metropolia i jej region $w$ gospodarce informacyjnej [The metropolis and its region in the information economy], Wydawnictwo Naukowe Scholar, Warsaw.

Grzelak, J., Zarycki, T. (eds.) (2004), Spoleczna mapa Warszawy. Interdyscyplinarne studium metropolii warszawskiej [The social map of Warsaw. An interdisciplinary analysis of the metropolis of Warsaw]. Wydawnictwo Naukowe Scholar, Warsaw.

Grzymała-Kazlawska, A., Piekut, A. (2007), 'Mala Ukraina' czy Polskie Viettown? Spoleczno-przestizenne wzory zamieszkiwania imigrantów w metropolii warszawskiej [Small Ukraine or Polish Viettown? Socio-spatial patterns of immigrants" locations in the Warsaw metropolis], Kwartalnik Studia Regionalne i Lokalne 4 (30). Wydawnictwo Naukowe Scholar, Warsaw, pp. 77-79.

Hall, P. (1993), Forces shaping urban Europe, $U r$ ban Studies, 30, 6: 883-898.
Hoyt, H., (1939), The structure and growth of residential neighborhoods in American cities, Washington, DC, Federal Housing Administration.

Jałowiecki, B. (2000), Spoleczna przestrzeń metropolii [The social space of the metropolis], Wydawnictwo Naukowe Scholar, Warsaw.

Jałowiecki, B., Krajewska, M., Olejniczak, K. (2004), Klasa metropolitalna w przestrzeni Warszawy [The metropolitan class in Warsaw space], in Grzelak, J., Zarycki, T. (eds.), Spoteczna mapa Warszawy. Interdyscyplinarne studium metropolii warszawskiej [The social map of Warsaw. An interdisciplinary analysis of the Warsaw metropolis], Wydawnictwo Naukowe Scholar, Warsaw, pp. 132-146.

Jałowiecki, B., Sekuła, E., Smętkowski, M, Tucholska, A., (2009), Warszawa. Czyjejest miasto? [Warsaw. Whose is the city?], Wydawnictwo Naukowe Scholar, Warsaw.

Jaroszewska-Brudnicka, R. (2004), Zróżnicowanie przestrzeni spolecznej Torunia [Differentaition of social space in Torun], Wydawnictwo Uniwersytetu Mikołaja Kopernika, Toruń

Kukliński, A. (ed.) (2004), Globalizacja Warszawy-strategiczny problem XXI wiek $a$ [The globalisation of Warsaw-a strategic challenge of the 21st century], Polskie Towarzystwo Wspólpracy z Klubem Rzymskim, Oficyna Wydawnicza Rewasz, Warsaw.

Lewicka, M. (2004), Identyfikacja z miejscem mieszkańców Warszawy: determinanty i konsekwencje [Warsaw inhabitants' identification with place: determinants and consequences], in Grzelak, J. Zarycki, T. (eds.), Spoteczna mapa Warszawy. Interdyscyplinarne studium metropolii warszawskiej [The social map of Warsaw. An interdisciplinary analysis of the Warsaw metropolis], Wydawnictwo Naukowe Scholar, Warsaw, pp. 273-315.

Lisowski, A. (1999), Koncepcja gentryfikacji jako przejaw tendencji integracji $w$ geografii miast [The gentrification concept as a manifestation of integration tendencies in urban geography], in Jażdżewska, I. (ed.) XI Konserwatoritum Wiedzy o Mieście, Zróżnicowania przestrzenne struktur spotecznych w duzych miastach, Katedra Geografii Miast i Turyzmu (GMiT), Uniwersytet Lódzki, Lódż, pp. 23-32. 
Młodak, A. (2006), Analiza taksonomiczna w statystyce regionalnej [Taxonomic analysis in regional statistics], Difin, Warsaw.

Musil, J. (1993), Changing Urban Systems in Post-communist Societies in Central Europe: Analysis and Prediction, Urban Studies, 30, 6: 899-905.

Nowosielska, E. (2005), Closing Remarks, in Nowosielska E., Parysek J. J. (eds.), Cities in the transforming post-Ccommunist countries: Ten years of economic, social and spatial experience, Geographia Polonica, 78, 1: 163-171.

Pacione, M. (2001), Urban geography-A global perspective, Routledge, London.

Parysek, J.J. (1989), Zróżnicowanie struktury wieku mieszkańców Polski [Differentiation to the age structure of inhabitants of Poland], Przeglad Geograficzny, 61, 3: 221-242.

Parysek J.J. (2005), Development of Polish towns and cities and factors affecting this process at the turn of the century, in Nowosielska, E., Parysek J.J. (eds.), Cities in the transforming post-Ccommunist countries: Ten years of economic, social and spatial experience, Geographia Polonica, 78, 1: 99-117.

Potrykowska, A., Śleszyński, P. (1999), Migracje wewnętrzne w Warszawie i województwie mazowieckim [Internal migration in Warsaw and Mazowieckie voivodship], Atlas Warszawy, 7, Instytut Geogrfii i Przestrzennego Zagospodarowania (IGiPZ), PAN, Warsaw.

Rebernik, D. (2005), Urbanization trends and processes of population change in the Ljubljana urban region in the 1990s, in Nowosielska, E., Parysek, J.J. (eds.), Cities in the transforming post-Ccommunist countries: Ten years of economic, social and spatial experience, Geographia Polonica, 78, 1: 67-78.

Smętkowski, M. (2005), New relationships between the metropolis and the region in information economy: Warsaw metropolitan region-A case study, in Eckardt, F., Hassenpflug, D. (eds.), Paths of urban transformation, The European City in Transition, vol. 5, Frankfurt, Peter Lang Verlag.

Smętkowski, M. (2007), Delimitacja obszarów metropolitalnych-nowe spojizenie [The delimitation of metropolitan areas-a new insight], in Gorzelak, G., Tucholska, A. (eds.), Roz- wój, region, przestrzeń [Development, region, space], MRR, EUROREG, pp. 215-233.

Smętkowski, M. (2009a), Miasto deweloperów? [A city of developers?], in Jałowiecki, B., Sekuła, E., Smętkowski, M., Tucholska, A. Warszawa. Czyje jest miasto? [Warsaw. Whose is the city?], Wydawnictwo Naukowe Scholar, Warsaw, pp. 8-88.

Smętkowski, M. (2009b), Zróżnicowania społeczno-przestrzenne Warszawy-inercja czy metamorfoza struktury miasta? [Socio-spatial differentiation of Warsaw: inertia or metamorphosis of the city structure?], Przeglad Geograficzny, 81, 4: 461-482.

Stępniak, M., Węcławowicz, G., Gorczyńska, M., Bierzyński, A. (2009), Warszawa w świetle Narodowego Spisu Powszechnego 2002 [Warsaw in the light of the 2002 National Census], Atlas Warszawy, 11, Instytut Geografii i Przestrzennego Zagospodarowania (IGiPZ), PAN, Warsaw.

Studium uwarunkowań i kierunków zagospodarowaniaprzestrzennego m. st. Warszawy [Study of the conditions and directions to spatial development of the capital city of Warsaw] (2006), Annex 3 to Resolution, LXXXII/2746/2006 of Warsaw Council dated as of 10 Dec. 2006.

Sykora, L. (1999), Processes of socio-spatial differentiation in post-communist Prague. Housing Studies, 14, 5: 679-701.

Śleszyński, P. (2004), Kształtowanie się zachodniej części centrum Warszawy [The shaping of the western part of Warsaw's Centre], Prace Geograficzne, 196, Instytut Geografii i Przestrzennego Zagospodarowania (IGiPZ), PAN, Warsaw.

Śleszyński, P. (2006), Przedsiębiorstwa w przestrzeni Warszawy [Enterprises in Warsaw spáce], Atlas Warszawy, 9, Instytut Geografii i Przestrzennego Zagospodarowania (IGiPZ), PAN, Warsaw.

The GEITONIES Project Report (2008), Generating interethnic tolerance and neighbourhood integration in European urban spaces, $7^{\text {th }}$ Framework Programme of the European Union, Grant no. 216 184, typescript.

Węcławowicz, G. (1975), Struktura przestrzeni spoleczno-gospodarczej Warszawy w latach 1931-1970 w świetle analizy czynnikowej [Structure of Warsaw socio-economic space 
in the years 1931-1970 based on factor analysis], Prace Geograficzne, 116, Instytut Geografii i Przestrzennego Zagospodarowania (IGiPZ), PAN, Warsaw.

Węctawowicz, G. (1988), Struktury spoteczno-przestrzenne w miastach Polski [Socio-spatial structures in Polish cities], Instytut Geografii i Przestrzennego Zagospodarowania (IGiPZ), PAN, Ossolineum, Wroclaw.

Węclawowicz, G. (2001), Przestrzeń ubóstwanowy czy stary wymiar zróżnicowania spoleczno-przestrzennego $w$ miastach Polski [Poverty space-a new or old dimension to the socio-spatial differentiation in Polish cities], Przeglad Geograficzny, 73, 4: 451-475.

Węcławowicz, G. (ed.) (2002), Warszawa jako przedmiot badań w geografii społeczno-ekonomicznej [Warsaw as research subject in socio-economic geography], Prace Geograficzne, 198, Instytut Geografii i Przestrzennego Zagospodarowania (IGiPZ), PAN, Warsaw.

Węclawowicz, G. (2007), Geografia spoteczna miast. Zróżnicowania spoleczno-przestrzenne [Urban social geography. Socio-spatial differentiation], Wydawnictwo Naukowe PWN, Warsaw.

Węclawowicz, G. (2008), Ludność z wykształceniem wyższym w strukturze spoleczno-przestrzennej Warszawy [The population with higher education in the socio-spatial structure of Warsaw] in: Warszawa Akademicka [Academic Warsaw], Instytut Problemów Współczesnej Cywilizacji, pp. 21-29.

Węcławowicz, G., Księżak, J. (1993), Zróżnicowania społeczno-przestrzenne Warszawy. Struktury demograficzne i gospodarstw domowych w świetle Narodowego Spisu Powszechnego 1988 [The socio-spatial differentiation of Warsaw. Demographic structure and households based on the 1988 National Census], Atlas Warszawy, 1, Instytut Geografii i Przestrzennego Zagospodarowania (IGiPZ), PAN, Warsaw.

Węcławowicz G., Księżak J. (1994), Zróżnicowania społeczno-przestrzenne Warszawy. Struktura wyksztalcenia i zatrudniania ludności w świetle Narodowego Spisu Powszechnego 1988 [The socio-spatial differentiation of. Warsaw. Educational attainment structure and employment based on the 1988 National Census] Atlas Warszawy, 2, Instytut Geografii i Przestrzennego Zagospodarowania (IGiPZ), PAN, Warsaw.

Wilk, W. (2001), Czynniki lokalizacji i rozmieszczenie wybranych ustug $w$ Warszawie [Factors underpinning the location and spatial distribution of services in Warsaw], Wydawnictwa Uniwersytetu Warszawskiego, Warsaw.

Wilk, W. (2005), Miejsce miast w sieciach handlowych-przykład Polski [The position of cities in retail chains-the case of Poland], in Lisowski, A. (ed.), Zmiany przestrzenne i funkcjonalne obszarów miejskich [Spatial and functional changes in urban areas], Prace $i$ Studia Geograficzne, 35, Wydawnictwa Uniwersytetu Warszawskiego, Warsaw, pp. 129-153.

Paper first received: September 2011

In final form: December 2011 
Annex 1. Principal components of Warsaw's socio-spatial differentiation (Varimax rotation)

\begin{tabular}{|c|c|c|c|c|c|}
\hline \multirow[b]{2}{*}{ Variable } & \multicolumn{5}{|c|}{ Components } \\
\hline & $\begin{array}{l}\text { Family } \\
\text { status }\end{array}$ & $\begin{array}{l}\text { Socio- } \\
\text { economic } \\
\text { status }\end{array}$ & $\begin{array}{l}\text { Social } \\
\text { margina- } \\
\text { lisation }\end{array}$ & $\begin{array}{l}\text { Popula- } \\
\text { tion } \\
\text { inflow } \\
\text { after } \\
1988\end{array}$ & $\begin{array}{l}\text { Youth } \\
\text { and } \\
\text { students }\end{array}$ \\
\hline Eigenvalue & 12.0 & 9.0 & 8.1 & 5.7 & 4.3 \\
\hline Total variation (\%) & 19.1 & 14.3 & 12.8 & 9.1 & 6.8 \\
\hline Population aged $0-14[\%]$ & 0.55 & -0.04 & 0.43 & 0.45 & -0.35 \\
\hline Population aged 15-24 [\%] & 0.39 & -0.05 & 0.12 & 0.01 & 0.84 \\
\hline Population aged $25-39$ [\%] & 0.22 & -0.07 & -0.19 & 0.74 & -0.37 \\
\hline Population aged $40-64[\%]$ & 0.43 & -0.13 & -0.24 & -0.72 & -0.02 \\
\hline Population aged over $65[\%]$ & -0.89 & 0.18 & 0.03 & -0.18 & -0.13 \\
\hline Single $[\%]$ & 0.19 & 0.07 & 0.06 & 0.16 & 0.81 \\
\hline Married [\%] & 0.65 & -0.02 & -0.30 & 0.08 & -0.52 \\
\hline Widow/widower $[\%]$ & -0.85 & -0.04 & 0.26 & -0.23 & -0.15 \\
\hline Divorced [\%] & -0.70 & -0.13 & 0.13 & -0.13 & -0.11 \\
\hline Population with tertiary education [\%] & 0.14 & 0.81 & -0.35 & 0.30 & -0.07 \\
\hline Population with secondary education [\%] & -0.22 & -0.43 & -0.20 & -0.24 & 0.52 \\
\hline Population with vocational education [\%] & -0.03 & -0.80 & -0.04 & -0.23 & -0.16 \\
\hline Population with elementary education [\%] & -0.05 & -0.47 & 0.76 & -0.16 & -0.15 \\
\hline Economically active population [\%] & 0.71 & 0.06 & -0.44 & 0.19 & -0.12 \\
\hline Unemployment rate $[\%]$ & -0.23 & -0.49 & 0.54 & -0.09 & 0.30 \\
\hline Employed in the elementary senvices sector [\%] & 0.13 & -0.59 & 0.33 & -0.04 & -0.30 \\
\hline Employed in the advanced services sector [\%] & -0.11 & 0.49 & -0.35 & 0.24 & -0.04 \\
\hline Employed in the public services sector [\%] & -0.06 & 0.27 & -0.30 & -0.01 & 0.43 \\
\hline Mànàgèrs [\%] & 0.41 & 0.61 & -0.02 & 0.17 & -0.26 \\
\hline Professionals [\%] & 0.00 & 0.79 & -0.40 & 0.22 & 0.09 \\
\hline Technicians [\%] & 0.02 & -0.10 & -0.44 & 0.01 & 0.03 \\
\hline Office personnel $[\%]$ & -0.17 & -0.55 & -0.10 & -0.27 & 0.16 \\
\hline Personal services and sale workers [\%] & -0.08 & -0.69 & 0.30 & -0.15 & -0.09 \\
\hline Workers, craftsmen, operators and assemblers [\%] & 0.02 & -0.72 & 0.40 & -0.24 & -0.16 \\
\hline People in elementary occupations [\%] & -0.30 & -0.54 & 0.53 & -0.16 & 0.04 \\
\hline People in paid employment [\%] & 0.77 & -0.08 & -0.24 & 0.32 & 0.05 \\
\hline Self-employed [\%] & 0.58 & 0.48 & 0.24 & 0.01 & -0.21 \\
\hline Dependent population [\%] & 0.62 & 0.06 & 0.49 & 0.25 & 0.27 \\
\hline Population arriving in the years 1998-2002 [\%] & 0.12 & 0.10 & 0.00 & 0.79 & 0.42 \\
\hline Population arriving from regional capitals [\%] & 0.04 & 0.29 & -0.14 & 0.78 & 0.20 \\
\hline Population arriving from rural areas [\%] & 0.04 & -0.14 & 0.07 & 0.62 & 0.54 \\
\hline People born outside Poland [\%] & -0.07 & 0.70 & 0.02 & -0.02 & -0.07 \\
\hline People born in Warsaw [\%] & 0.12 & -0.17 & 0.30 & -0.38 & -0.38 \\
\hline
\end{tabular}




\begin{tabular}{|c|c|c|c|c|c|}
\hline \multirow[b]{2}{*}{ Variable } & \multicolumn{5}{|c|}{ Components } \\
\hline & $\begin{array}{l}\text { Family } \\
\text { status }\end{array}$ & $\begin{array}{l}\text { Socio- } \\
\text { economic } \\
\text { status }\end{array}$ & $\begin{array}{l}\text { Social } \\
\text { margina- } \\
\text { lisation }\end{array}$ & $\begin{array}{l}\text { Popula- } \\
\text { tion } \\
\text { inflow } \\
\text { after } \\
1988\end{array}$ & $\begin{array}{l}\text { Youth } \\
\text { and } \\
\text { students }\end{array}$ \\
\hline People coming to Warsaw before 1988 [\%] & -0.28 & 0.01 & -0.36 & -0.48 & -0.03 \\
\hline People coming to Warsaw in the years $1989-1995$ [\%] & 0.28 & 0.16 & -0.01 & 0.65 & 0.03 \\
\hline One-person households [\%] & -0.87 & 0.11 & 0.01 & 0.08 & 0.03 \\
\hline Two-person households [\%] & -0.50 & -0.02 & -0.35 & -0.02 & -0.21 \\
\hline Three and four-person households [\%] & 0.94 & -0.08 & 0.01 & -0.03 & 0.06 \\
\hline Households with five or more persons [\%] & 0.65 & -0.08 & 0.49 & -0.15 & 0.01 \\
\hline Families with dependent children [\%] & 0.77 & 0.01 & 0.35 & 0.22 & 0.09 \\
\hline $\begin{array}{l}\text { Families with many children (more than five } \\
\text { dependent children) [\%] }\end{array}$ & 0.24 & 0.01 & 0.54 & 0.01 & 0.06 \\
\hline Single parents with dependent children [\%] & -0.64 & -0.27 & 0.35 & -0.34 & 0.07 \\
\hline Partners with children [\%] & 0.00 & 0.06 & 0.38 & 0.29 & -0.02 \\
\hline Flats owned by private individuals [\%] & -0.09 & 0.28 & 0.61 & 0.15 & -0.15 \\
\hline $\begin{array}{l}\text { Flats owned by individuals members of housing } \\
\text { cooperative [\%] }\end{array}$ & 0.21 & 0.03 & -0.72 & -0.08 & -0.05 \\
\hline Flats owned by housing cooperative [\%] & 0.31 & -0.40 & -0.56 & -0.26 & -0.02 \\
\hline Flats owned by municipality [\%] & -0.44 & -0.21 & 0.62 & -0.02 & 0.06 \\
\hline Unoccupied flăts [\%] & 0.16 & 0.30 & 0.25 & 0.47 & -0.19 \\
\hline Flats used for business activity [\%] & -0.07 & 0.44 & 0.23 & -0.05 & 0.01 \\
\hline Abandoned flats $[\%]$ & 0.09 & -0.02 & 0.47 & 0.01 & -0.01 \\
\hline Number of persons per flat & 0.45 & -0.11 & 0.15 & 0.07 & 0.63 \\
\hline Floor area per person & 0.38 & 0.76 & 0.17 & -0.01 & -0.32 \\
\hline Substandârd flâts $[\%]$ & -0.13 & -0.22 & 0.73 & 0.04 & 0.03 \\
\hline Flats of floor area under $49 \mathrm{~m}^{2}[\%]$ & -0.77 & -0.46 & -0.03 & 0.10 & -0.04 \\
\hline Flats of floor area $50-100 \mathrm{~m}^{2}[\%]$ & 0.67 & 0.26 & -0.22 & -0.10 & 0.16 \\
\hline Flats of floor area above $100 \mathrm{~m}^{2}[\%]$ & 0.40 & 0.49 & 0.44 & -0.02 & -0.19 \\
\hline Buildings built before 1944 [\%] & -0.08 & 0.13 & 0.63 & -0.09 & 0.04 \\
\hline Buildings built in the years $1945-1970$ [\%] & -0.77 & -0.02 & 0.13 & 0.04 & 0.01 \\
\hline Buildings built in the years 1971-1988 [\%] & 0.44 & -0.22 & -0.53 & -0.36 & 0.06 \\
\hline Buildings built in the years $1989-2002$ [\%] & 0.58 & 0.24 & 0.01 & 0.60 & -0.14 \\
\hline Total immigrants $[\%]$ & -0.07 & 0.55 & 0.15 & 0.08 & 0.15 \\
\hline Immigrants from Vietnam [\%] & -0.01 & 0.46 & 0.14 & -0.12 & -0.03 \\
\hline Immigrants from EU countries and the USA [\%] & -0.03 & 0.59 & 0.17 & -0.10 & 0.00 \\
\hline
\end{tabular}

Source: prepared by the author on the basis of Central Statistical Office data. 
http://rcin.org.pl 


\section{REFEREES AND ADVISERS TO GEOGRAPHIA POLONICA 2010-2011}

The Editors would like to express their warmest thanks to all the reviewers and advisers for their effort, commitment and invaluable contribution in reviewing the papers submitted to Geographia Polonica.

Kazimierz BANASIK

Renata BEDNAREK

Wojciech CHEŁMICKI

Dariusz CISZEWSKI

Wojciech FROEHLICH

Piotr GĘBICA

Joseph GUTTMAN

Vladimir IRA

Jacek JANIA

Eamonn JUDGE

Adam KOTARBA

Ossi KOTAVAARA

Mariusz KOWALSKI

Kazimierz KRZEMIEŃ

Mariusz KULESZA
Warsaw University of Life Sciences (SGGW), Warszawa, Poland

Department of Soil Science, Institute of Geography, Nicolaus Copernicus University, Poland

Institute of Geography and Spatial Management, Department of Hydrology, Jagiellonian University, Kraków, Poland

Institute of Environment Protection, Kraków, Poland

Institute of Geography and Spatial Organization PAS, Poland

University of Information Technology and Management in Rzeszów, Poland

Mekorot Water Company, Tel Aviv, Israel

Slovak Academy of Sciences, Institute of Geography, Bratislava, Slovakia

Department of Environmental Remote Sensing, Silesian University, Sosnowiec, Poland

Policy Research Institute, Leeds Metropolitan University, UK

Institute of Geography and Spatial Organization PAS, Poland

Department of Geography, University of Oulu, Finland

Institute of Geography and Spatial Organization PAS, Warszawa, Poland

Jagiellonian University, Poland

Department of Historical Geography and Cultural Heritage, University of Lódż, Poland 
Zbigniew KUNDZEWICZ

Andrzej MIZGAJSKI

Lucas MENZEL

Artur MAGNUSZEWSKI

Zdeněk LIPSKÝ

Adam ŁAJCZAK

Maria ŁANCZONT

Miroslav MARADA

René MATLOVIC

Heinz-Theo MENGELKAMP

Daniel MICHNIAK
Polish Academy of Sciences, Institute for Agricultural and Forest Environment, Poznań, Poland

Adam Mickiewicz University, Department of Integrated Geography, Poznań, Poland

Heidelberg University, Germany

Department of Geography and Regional Studies, University of Warszawa, Poland

Charles University in Prague, Czech Republic

Faculty of Earth Sciences, University of Silesia, Poland

Maria Curie-Skłodowska University, Poland

Charles University in Prague, Faculty of Science, Czech Republic

Faculty of Humanities and Natural Science, University of Prešsov, Slovakia

Institute for Atmospheric Physics, Germany

Slovak Academy of Sciences, Institute of Geography, Bratislava, Slovakia

Valentin Todorov MIHAYLOV Sofia, Bulgaria

Andrzej MIZAGAJSKI

Edward MOJSKI

Elżbieta MYCIELSKA-

-DOWGIALLO

Marian OSTROZ̆LIKK

Aneta PIEKUT

Zofia RĄCZKOWSKA

Andrzej RICHLING

Phil REES

Roman SOJA

Jerzy SOLON

Alfred STACH

Wojciech STANKOWSKI

Dariusz ŚWIĄTEK
Adam Mickiewicz University, Department of Integrated Geography, Poznań, Poland

Polish Geological Institute, Poland

University of Warsaw, Poland

Geophysical Institute of the Slovak Academy of Sciences, Bratislava, Slovakia

School of Geography University of Leeds, UK

Institute of Geography and Spatial Organization PAS, Poland

Faculty of Geography and Regional Studies, University of Warsaw, Poland

School of Geography, University of Leeds, UK

Institute of Geography and Spatial Organization PAS, Poland

Institute of Geography and Spatial Organization, PAS, Poland

Adam Mickiewicz University, Institute of Geoecology and Geoinformation, Poznań, Poland

Higher School of Economy in Bydgoszcz, Poland

Institute of Geography and Spatial Organization PAS, Poland 
Alexey TITKOV

Piotr TRZEPACZ

Jan WINTER

Vít VILIMEK

Xenia VOLOSHENKO

Witold ZUCHIEWICZ
Moscow School of Social and Economic Sciences, Russia

Jagiellonian University, Institute of Geography and Spatial Management, Poland

Institute of Meteorology and Water Management, Poland

Charles University in Prague, Czech Republic

Research and Education Center «Regional studies», I.Kant Baltic Federal University, Russia

AGH University of Science and Technology, Poland 
http://rcin.org.pl 


\section{CONTENTS}

\section{ARTICLES}

\section{TERESA CZYŻ}

Conceptions of an urban agglomeration and a metropolitan area in Poland

\section{AGNIESZKA BIELEWSKA}

The settlement patterns of Polish immigrants in Manchester in the context of move from modern to postmodern understanding of place

\section{GÉZA TÓTH AND ÁRON KINCSES}

New aspects of European road accessibility

TOMASZ KOMORNICKI AND PRZEMYSŁAW ŚLESZYŃSKI

Changing accessibility of Polish airports on the course of demographic and economic demand

\section{TAMÁS MIZIK}

The "CIS effects" of Russia's forthcoming WTO accession

\section{ZBIGNIEW TAYLOR AND ARIEL CIECHAŃSKI}

Organizational restructuring and ownership transformation in Poland's inland shipping companies after 1990

\section{ROMAN MATYKOWSKI AND KATARZYNA KULCZYŃSKA}

Polish presidential election of 2010: a study of the power of voters in big and medium-sized towns MACIEJ SMĘTKOWSKI

Socio-spatial differentiation in Warsaw: inertia or metamorphosis of the city structure?

REFEREES AND ADVISERS TO GEOGRAPHIA POLONICA 2010—2011 